Catherine Mary MacRobert (Oxford)

\title{
The Place of the Mihanović Psalter IN THE FourteENTH-CENTURY REVISIONS of the Church Slavonic Psalter
}

\begin{abstract}
A mong the revised versions of Church Slavonic biblical and liturgical texts from the early fourteenth century, the Psalter occupies a special place, because it appears in two related but distinct revisions of approximately the same date. One

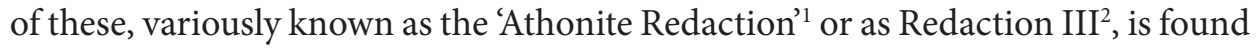
in Bulgarian manuscripts of the late thirteenth or early fourteenth century, notably the Šopov-Karadimov psalter fragments in Sofia ${ }^{3}$, and the Mihanović psalter fragments, HAZU III a 49 and NSK R. 4494/1, in Zagreb; Serbian copies ${ }^{4}$ are extant from the mid fourteenth century onward, and the redaction seems to have been in widespread use in the South Slav lands: it was printed in the Cetinje Psalter at the end of the fifteenth century. The other early fourteenth-century revision of the Church Slavonic Psalter is so far attested only in one manuscript, the Bulgarian Norov Psalter ${ }^{6}$. In Thomson's classification this is Redaction IV ${ }^{7}$.

As is shown in Karačorova's contrastive studies ${ }^{8}$ of the early textual tradition and the fourteenth-century revisions of the Church Slavonic Psalter, Redactions
\end{abstract}

\footnotetext{
${ }^{1}$ Е.В. Чешко, Об абонской редакиии славянского перевода псалтьри в ее отночении к другим редакииям, [in:] Язык и письменность среднеболгарского периода, ed. Е.В. ЧЕшко et al., Москва 1982, p. 60-93.

${ }^{2}$ F. J. Thomson, The Slavonic Translation of the Old Testament, [in:] Interpretation of the Bible, ed. J. KRašoveC, Ljubljana-Sheffield 1998, p. 815-820.

3 Plus a fragment recently discovered in the Central State Archive in Constantinople, see Е. Мусакова, Новооткрит фрагмент от Шоповия-Карадимов псалтир, [in:] Богослужебните книги - познати и непознати, София 2008, р. 27-35.

${ }^{4}$ C.M. MacRobert, Problems in the study of the 'Athonite' redaction of the Psalter in South Slavonic manuscripts, [in:] Studies of Medieval South Slavic Manuscripts. Proceedings of the $3^{\text {rd }}$ International Hilandar Conference held from March 28 to 30,1989= Проучаване средновековних јужнословенских рукописа. Зборник радова са III међународне Хиландарске конферениије одржане од 28. до 30. марта 1989, еd. П. Ивић, Београд 1995, р. 195-213.

${ }^{5}$ Д. МАртиновић, Псалтир с последоваюем Ђурђа Црнојевића 1494, Cetinje 1986.

${ }^{6}$ Норовская псалтыьрв: Среднеболгарская рукопись ХIV века, I-II, ed. Е.В. Чешко et al., София 1989.

${ }^{7}$ F.J. Thomson, op. cit., p. 820.

${ }^{8}$ И. КАРАчОРОвА, Към вбпроса за Кирило-Методиевския старобблгарски превод на псалтира, KMc 6, 1989, p. 130-245; ЕАDEм, Кәм изучаването на псалтирните редакции от XIV в.
} 
III and IV have much in common: they share not only a large number of individual readings, but also recurrent instances of systematic lexical preferences, e.g. ckopo,

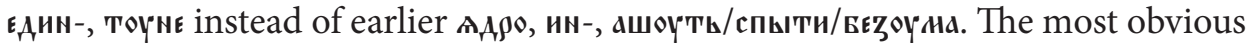
difference between them consists in their relationship to the Greek text and to the previous Church Slavonic versions. Redaction III has clearly been reworked with reference to Greek, but the resulting changes are limited in type and extent; behind them elements of the older Redactions I and II can readily be detected. By contrast, Redaction IV reflects a much more radical attempt to align Church Slavonic syntax and morphology with Greek: verbal rection tends to be influenced by the choice of case in Greek'; the distribution of prepositional phrases is based more closely on Greek usage than in Redaction III, including the systematic use of conjunctions and prepositions to govern infinitives ${ }^{10}$; $\boldsymbol{\epsilon}$ \& is regularly deployed as the equivalent of the Greek definite article to introduce attributive prepositional phrases and nominalized infinitives ${ }^{11}$; as far as possible, the word order of Greek is reproduced, e.g. by treating the traditional postposition Ряди as a preposition ${ }^{12}$; reflexive verbs, rather than passive participles, correspond to Greek passive forms ${ }^{13}$; Slavonic prefixes are added to verbs, either in response to local norms or in strict imitation of Greek ${ }^{14}$, producing instances of double prefixation unusual in earlier

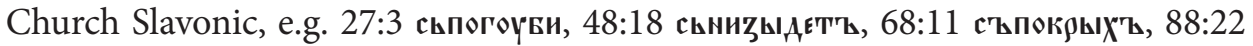

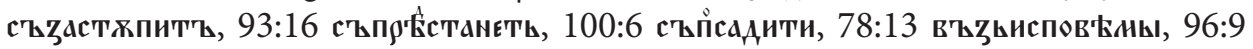

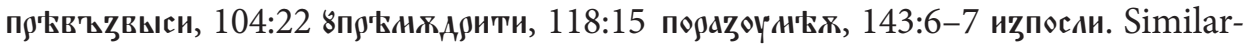
ly, one-to-one correspondences between Church Slavonic and Greek lexical items are imposed, such as the calques въzвыситисл rather than в'ъднестисл I II III for

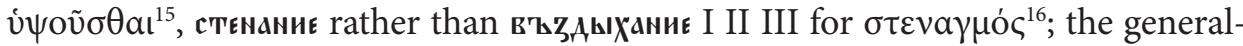

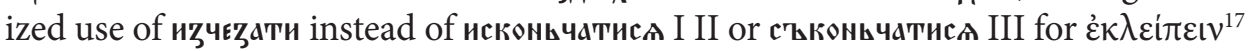

(Библейски песни), [in:] Нтоть оученикъ надъ оучителемь своимъ. Сборник в чест на проб. дфн Иван Добрев, член-кореспондент на БАН и учител, еd. А.-М. ТотомановА, Т. СлАвовА, София 2005, p. 345-356.

${ }^{9}$ Норовская псалтырь..., I, р. 72-74; И. КАРАчоровА, Кбм изучаването..., p. 349-350.

10 Е.В. ЧЕшко, Кирилло-мефодиевский перевод Псалтыри и среднеболгарские правленые редакции. Структура слова и реляиионные элементы, [in:] Studia slavico-byzantina et mediaevalia europensia, I, ed. П. Динеков et al., София 1988, p. 224-226; Норовская псалтырь..., I, p. 70-71; И. КАРачоровА, op. cit., p. 350; С.M. MacRoвеRT, Maksim Grek in linguistic context, [forthcoming in:] Latinitas in the Slavic World, ed. V.S. TOMELLERI [PhS].

${ }^{11}$ Е.В. Чешко, Кирилло-мебооиевский перевод..., р. 225-226; Норовская псалтырь..., I, р. 70; И. КАРАчоровА, Кбм вбпроса..., р. 154-156; ЕАDЕм, Кбм изучаването..., р. 349; С.М. МАС ROBERT, op. cit.

${ }^{12}$ Норовская псалтырь..., I, р. 71-72; И. КАРАЧОРОвА, ор. cit., p. 350.

${ }^{13}$ Е.В. Чешко, Кирилло-мебодиевский перевод..., р. 228.

${ }^{14} \mathrm{Ibidem}$, p. 220-222; И. КАРАЧОРОВА, Кбм вбпроса..., p. 198; ЕАDЕм, Кбм изучаването..., p. 352.

${ }^{15}$ Е.В. ЧЕшко, Кирилло-мефодиевский перевод..., р. 223; Норовская псалтырь..., I, р. 68.

${ }^{16}$ In 11:6, 30:11, 37:9-10, 101:6, 101:21, but not 6:7, 78:11.

${ }^{17}$ Е.В. ЧЕшко, Кирилло-мефодиевский перевод..., р. 222. 


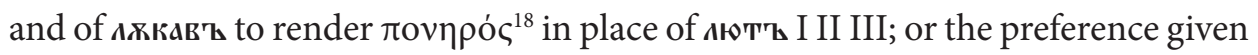

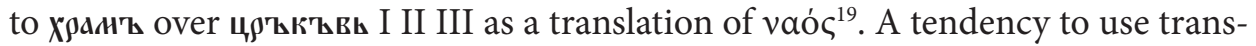
lations rather than loanwords is sporadically discernible, for instance the three

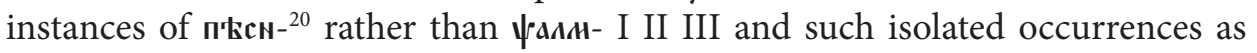
42:4 ж९ьтьвникоу for өлтарю I II III, 44:8 насль for өлћи I II єлєи III. Redaction IV also goes further than Redaction III in morphological and syntactic developments such as increased use of the pronoun $\mathbf{T}_{\mathbf{b}}{ }^{21}$, the reduplicated stem $\mathrm{AdA}_{\mathrm{A}}$ - in aorist forms $s^{22}$, the animate accusative of pronouns ${ }^{23}$ and the dative case in correspondence to Greek genitive ${ }^{24}$.

At the same time Redaction IV is not a totally new translation, independent of what came before. Even in its imitations of Greek infinitival constructions it sometimes betrays, through incoherence or inconsistency, its dependence on the wording of Redactions I, II and III, e.g.:

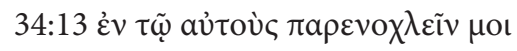

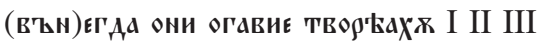

вьнегда шни шгавствовати дї IV

In imitation of Greek an infinitive has been substituted here for a finite verb, but the required concomitant change from nominative to dative subject has not been carried through.

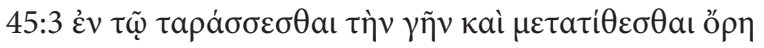

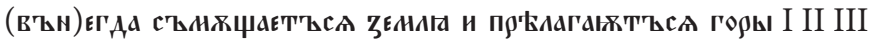

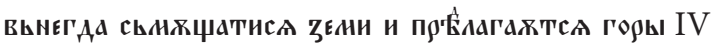

The first of two conjoined verbs has been changed to an infinitive, as in Greek, but either the reviser has neglected to change the second verb, or the scribe has copied a finite form from a conservative exemplar.

\footnotetext{
${ }^{18}$ In 33:22, 36:19, 48:6, 77:49, but not 40:2, 93:13, 143:10.

${ }^{19}$ In 17:7, 26:4, 28:9, 44:16, 64:5, 67:30, 78:1, 143:12, but not 5:8, 10:4, 27:2, 137:2.

${ }^{20}$ In $70: 22,107: 3,151: 3$.

${ }^{21}$ E.g. 77:6.

${ }^{22}$ E.g. 111:9, 115:3.

${ }^{23}$ И. КАРАчорова, Кбм изучаването..., p. 348; C.M. MaсRовеRт, The variable treatment of clitics in $14^{\text {th }}$-century South Slavonicpsalter translations, [in:] Многократните преводи в Южнославяското Средновековие. София, 7-9 юли 2005, еd. Л. ТАСевА, Р. МАРтИ, М. ЙовчевА, Т. ПЕНТковСКАЯ, София 2006, p. 381-382.

${ }^{24}$ E.g. 28:6, 44:13, 77:61, 100:4, 105:22.
} 


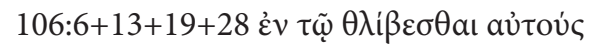

(вън)єГда въСттжжишА I II III

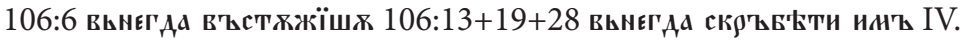

Conversely to the previous example, a finite verb is retained from earlier redactions in the first instance, but replaced by an infinitive on the model of Greek in subsequent iterations.

Perhaps because the Grecizing tendency in Redaction IV is so strong, less scholarly attention has been given to the differences in native Slavonic usage between it and Redaction III. Yet these are also systematic, and they complicate the relationship between the two redactions. In some respects Redaction III follows the tradition of Redactions I and II, while Redaction IV innovates, for instance by preferring вєликт ${ }^{25}$ and танио ${ }^{26}$ tо вєлии and тоу. At the same time, however, Redaction IV retains consistently the verb стынстисл as in I and II, whereas Redaction III just as consistently replaces it with съмжтитисл. Both redactions vacillate between the old loanword х calque поназаныи, but in different distributions: in 104:15, 131:10+17 Redaction III has помазаныи while Redaction IV has христ'ъ, but in 88:39 Redaction IV has поназаныи whereas Redaction III has христт. Thus neither redaction can be explained simply as a modification or elaboration of the other: they relate to previous tradition in different ways and, for all their similarities, they reflect divergent Slavonic norms.

A direct textual relationship between Redaction IV and earlier versions, unmediated by Redaction III, is also demonstrated by the number of early readings which are reproduced in IV but are alien to III ${ }^{27}$. Some of these are standard in Redactions I and II, reflecting either their Greek textual tradition or their shared approach to translation and interpretation:

\section{Revisions in III}

$2: 12,7: 3,12: 4+5,27: 1,37: 17,49: 22 \mu$ п்

\section{Early readings in IV}

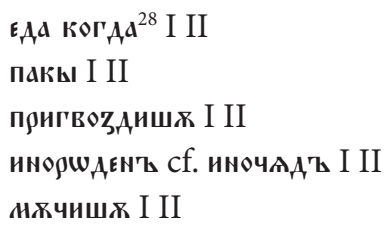

\footnotetext{
${ }^{25}$ In $20: 6,46: 3,47: 2,76: 14,85: 13,88: 8,94: 3,98: 2,105: 21,107: 5,110: 2,134: 5,137: 5,144: 3,146: 5$. This form also appears sporadically in Redaction II.

${ }^{26}$ In 35:13, 47:7, 68:36, 121:5, 131:17, 132:3, 136:1+3, 138:8+10.

${ }^{27}$ Норовская псалтырь..., I, p. 75-76.

${ }^{28}$ In the first four instances
} 
41:2 оÜ

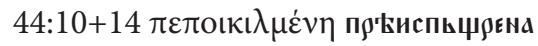

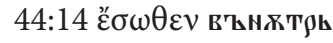

46:10 оі кратаıоі А९ьжавьнии

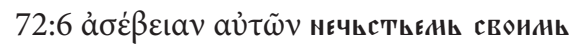

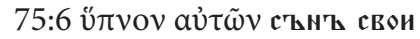

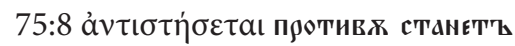

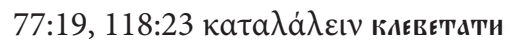

80:5 кріна скдыьEа

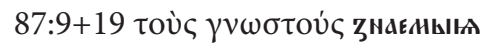

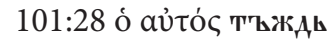

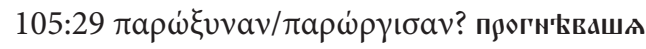

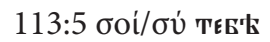

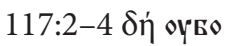

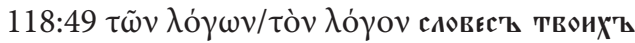

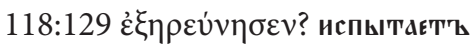

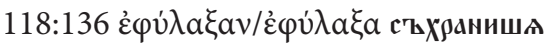

120:8 vข̃v พ̈H'E таке I II

пртоүкрашена I II

вьнатрLда ОY I II

кө'пции I II

NЕЧЕСТИЕХ СВОЕХ I II

СнОА'Ъ СВОНА' I II

противитеА I II

ГАати I II

сжАт I II

zнанныж сf. знанита I II

сан'b I II

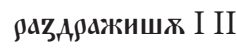

ты I II

NH' I II

САOBO TROE I II

ндпьта I II

с'ъхранихъ I II

cEAt I II

Others are peculiar to Redaction I or are even minority variants known only from a few early manuscripts:

\section{Revisions in III}

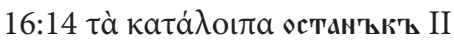

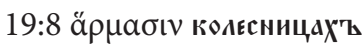

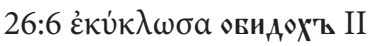

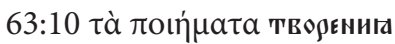

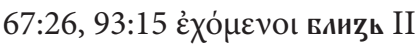

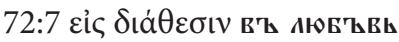

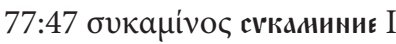

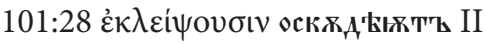

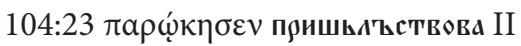

\section{Early variants in IV}

ш̋љккы I

ш९жжиї minority reading in I II

овид' I

твари I

Adt' I

в' АюБви I

ч९ьКИЧнЕ $\mathrm{cf}$. Ч९ьнИЦА variant in I

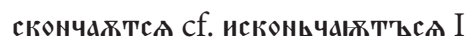
пюиїAв I

The readings cited above are the more striking instances where Redaction IV follows earlier tradition; an attentive reading of Karačorova's studies will supply further examples. The fact that some of these vestigial early readings are unusual should not occasion surprise: very conservative versions of the Church Slavonic translation, such as the Pogodin and Sofia Psalters, were still being copied in late thirteenth and early fourteenth-century Bulgaria. In addition, the sporadic indications of diapsalmata in the Norov Psalter have parallels almost exclusively in Redac- 
tion $\mathrm{I}^{29}$; they might of course have been reproduced directly from Greek, but this seems less likely, since they tend to be omitted from later Greek manuscripts ${ }^{30}$.

There is clearly a problem here: Redactions III and IV, as well as displaying both coincidences and divergences in their innovations, contain different sets of readings retained from earlier redactions. Consequently there seems to be no straightforwardly reliable way of deriving one version from the other on the basis of internal evidence: each appears to relate to earlier tradition independently of the other. For this reason, arguments for the priority of one or other redaction have been based on the date of their manuscripts. Starting from the traditional dating of the Norov Psalter to the later thirteenth century, and from the dissemination of Redaction III in the fourteenth century, Češko and Karačorova assumed that Redaction IV came first ${ }^{31}$ and Redaction III was a subsequent modification, a compromise between its radical Grecizing stance and older tradition. But the Norov Psalter is now thought to date from the early fourteenth century ${ }^{32}$, and Thomson has argued that Redaction III preceded it $^{33}$. His argument appears to rely on Mošin's dating ${ }^{34}$ of the Mihanović Psalter fragment, which largely follows Redaction III, to the late thirteenth century. However, Jagić referred the Mihanović Psalter to the early fourteenth centur $y^{35}$, and recently this dating has been revived by Turilov ${ }^{36}$, on the grounds that the manuscript was written by the same scribe as the first and main hand of the Norov Psalter. If this is the case, it undermines any attempt to derive the chronological sequence of the two redactions from the dates of these manuscripts; it also brings into sharper focus the problem of the textual relationship between them.

The primary affiliation of the Mihanović Psalter to Redaction III is beyond doubt: it exhibits not only the textual features which are shared by both the early fourteenth-century revisions, but also the range of variants mentioned above which set Redaction III apart from Redaction IV, both in those places cited above ${ }^{37}$

\footnotetext{
${ }^{29}$ C.M. MacRobert, On the headings and marginal notes in the two Glagolitic psalter manuscripts in S. Catherine's Monastery on Mount Sinai, [in:] Philology Broad and Deep: In Memoriam Horace Gray Lunt, ed. M. S. Flier, D. J. Birnbaum, C.M. Vakareliyska, Bloomington, IN 2014, p. 177-179. ${ }^{30}$ A. Rahlfs, Septuaginta, vol. X, Psalmi cum Odis, Göttingen $1979^{3}$, p. 77.

${ }^{31}$ Е.В. ЧЕшко, Об аббонской редакции..., р. 86; И. КАРАЧОРОвА, Към въпроса..., р. 133, 239-240.

${ }^{32}$ Норовская псалтырь..., р. 48-49.

${ }^{33}$ F.J. Thomson, op. cit., p. 815.

${ }^{34}$ V. Mošin, Ćirilski rukopisi Jugoslavenske akademije, Zagreb 1955, I, p. 55-6, II, p. 13-14.

${ }^{35}$ V. JAgIć, Zwei illustrierte serbische Psalter (= introduction to J. STRZYGowski, Die Miniaturen des Serbischen Psalters der Königlichen Hof- und Staatsbibliothek in München), DKAW.PhH 52.2, 1906, p. lxv-lxxi.

${ }^{36}$ А.А. Турилов, Болгарские книжники раннего XIV в. между Тырновом, Святой горой и Святой землей, КМс 21, 2012, p. 236-239.

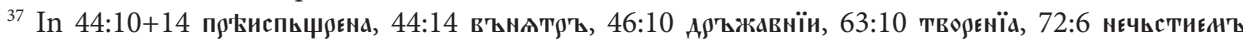

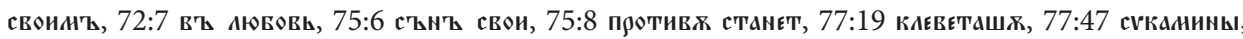


where Redaction IV is conservative, and also in some places where the two redactions innovate:

\section{Revisions in III and Mihanović Psalter}

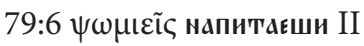

104:20 å

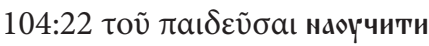

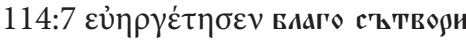

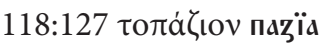

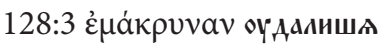

\section{Readings in other redactions}

натрОВеши I, НасьШтТЕши IV

испоусти I II ӥпоүсти IV

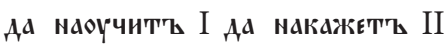
еже наказатти IV

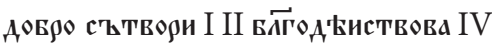
Tv[н]па[н]зига I II топаzїа IV

弓адА'ъжишА I II оүАльжишж IV

In addition, the Mihanović Psalter displays a peculiarly systematic use of съдиятити $(\mathfrak{c} A)$, not only in the numerous places where other manuscripts of Redaction III deploy this verb ${ }^{38}$ but also in $64: 8^{39}$ and $67: 5^{40}$.

As a witness to Redaction III, however, the Mihanović Psalter is unusual in two ways. Firstly, it contains more inherited readings, especially from Redaction I, than do most of the other witnesses to Redaction III $^{41}$. In its partial retention of old accusative pronominal forms it presents the appearance of an incomplete revision, but there are also more substantive relics of early tradition:

\section{Revisions in III and IV}

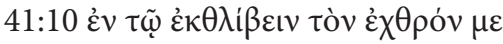

ЕГАА стТЖААЕТ'Қ НИ в९аГ' III

вьнегда сттЖЖтти в९агоY IV

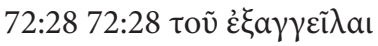

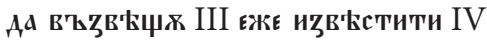

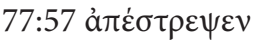

овратишАсА III ш̈вратишж са IV

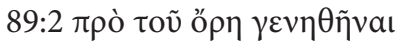

\section{Early readings in Mihanović Psalter}

ш̈ ПЕчали в९аГа I II

Ad испов'ьн'ъ I II

възвратишжся I II

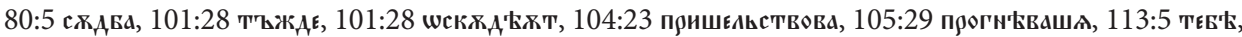

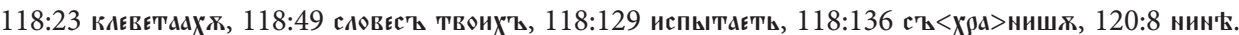
${ }^{38}$ In 41:7, 45:4, 45:7, 47:6, 54:3, 54:5, 59:4, 63:9, 76:5, 82:16, 89:7, 106:27, 118:60; 82:18, also 75:6

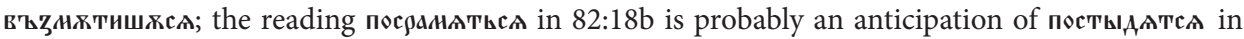
the second half of the verse.

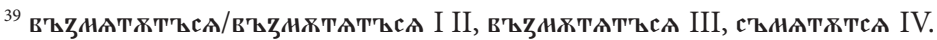

${ }^{40}$ C'ҚHATRT'ҺCA I II III IV.

${ }^{41}$ C.M. MacRobert, Problems..., p. 211. 


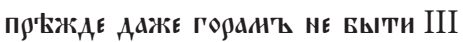
ПрТЖАЕ єЖе ГШ९ан'ъ БЫти IV

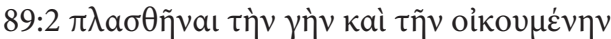

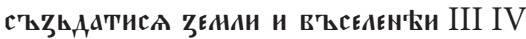
54:14 $\gamma \nu \omega \sigma \tau \dot{\varepsilon} \mu$ о

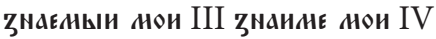

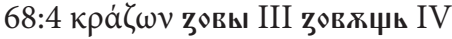
101:10 Ö TI zane III rako IV

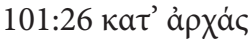

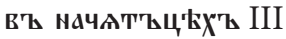

в' начАлшХ'ъ IV

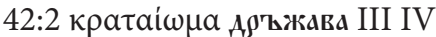

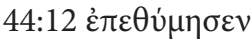

в'ҚЖАЕА'ЕЕТ'Қ III в'ҚZЖЕААЕТТ IV

55:13 ai عủxai нолитвы III IV

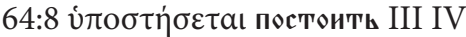

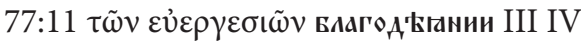

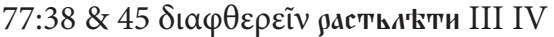

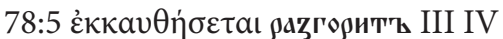

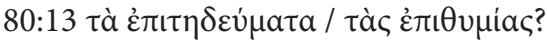

начинанию III начинании IV
П९КЖАЕ ААЖЕ ГО९Ы НЕ БЫША I II

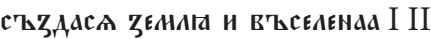

zHahHe hoe I II

в'ไกия I II

ИАE I II

вไ НАЧАТТКК I II

кр'пость I II

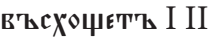

ов'тии I II

ПООТТИВ及 СТАНЕт'Қ I II

БАГОдатти I II

погоувити I II

९АЖАЕЖЕтТЪ I II

ПОХOTEM'В ${ }^{42}$ I II

Rather as in Redaction IV, these earlier readings are sometimes conservative or minority variants:

\section{Shared readings in III and IV}

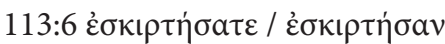

въzыграстес АII IV, minority reading in I

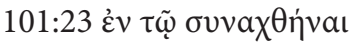

(вън)єГАА С'ВБербТ'ЫСА II III

в'ВнеГда С'ЪБОатисА IV

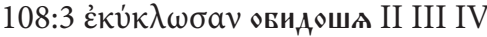

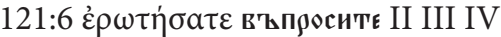

Early variants in Mihanović Psalter

възыграшжсл I II

EГAА С'BHLARTCA I

ШБыдж I

OунОлите I

It may be mere chance that inherited readings in the Mihanović Psalter are also found in Redaction IV, but the fact that some of them recur in the same distribution as in the Norov Psalter looks like more than coincidence:

${ }^{42}$ A reminiscence, whether in Greek or in Church Slavonic, of 9:24 and 20:3. 


\section{Revisions in III}

41:2 оÜ $\omega \varsigma$ сице

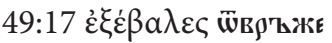

58:12 ката́)аүє низложи

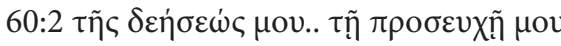
MOAENHE HOE... HOAИTER HOK

64:11 $\mu \dot{\theta} \theta$ vог оүпои

69:6 хроуібпฺ закъсни

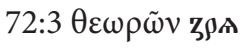

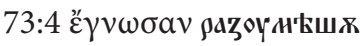

74:9 тойто сия

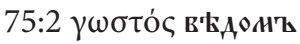

$86: 3 \delta \varepsilon \delta$ б $\alpha \sigma \mu \varepsilon \dot{\varepsilon} v \alpha \dot{\varepsilon} \lambda \alpha \lambda \dot{\eta} \theta \eta$

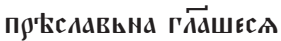

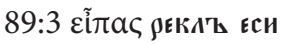

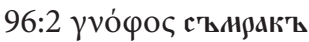

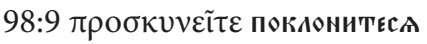

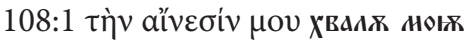

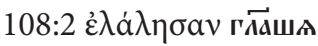

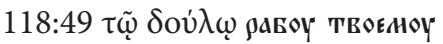

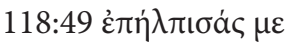

оүПъванИе ААА'Ъ МИ ЕсИ

127:6 '̊оıс видиши

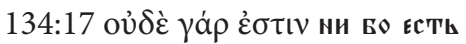

\section{Early readings in Mihanović Psalter and IV}

TaKo $0^{43}$ I II

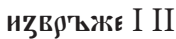

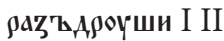

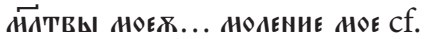

НОЛИТТВ НО1Х... HOAENHE HOE I II

напои I II

занндА्. ${ }^{44}$ I II

BIAA I II

познашж I

OHX I II

ZНАEल'Ъ I II

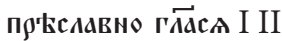

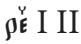

норак'ы I II

КАан'Биттес I II

ХвАлЫ МОеж I II

въъг

gава твоего I II

ан'大 оүПОвание Ада Еси I II

оүзоїши I II

н'大сть БW I II

Once again, part of this common inheritance is conservative and even unusual:

\section{Shared readings in III}

86:7 ¿̇V бÖ OY TEE I II III

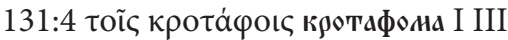

$72: 1$ ஸৎ коль I II III

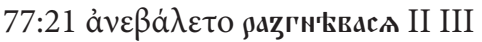

\author{
Early variants in Mihanović Psalter and IV \\ B' T' TÉ \\ скранїана II \\ тако minority reading in I

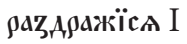

Of particular interest are the places where the Mihanović Psalter appears to duplicate the patterns of distribution noted above in Redaction IV:

\footnotetext{
${ }^{43}$ Corrected in the Mihanović Psalter to сицє.

${ }^{44}$ The Norov Psalter also had this reading originally in 39:18.
} 


\section{Revisions in III}

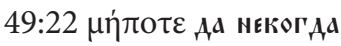

77:17 हैंน єџє

104:15, 131:10 \& 17 хрเбто́ помаzаныи

\section{Early variants in Mihanović Psalter and IV}

\author{
EAd KOrAd I II \\ пакы I II \\ Хенст'ъ I II
}

Unfortunately the fragmentary state in which the Mihanović Psalter has survived ${ }^{45}$ makes it impossible to establish exactly how many early readings it shared with the Norov Psalter.

The second and more remarkable peculiarity of the Mihanović Psalter is that it shares some of the distinctive new readings of Redaction IV. The examples of shared lexis and parallel grammatical innovation are limited in number, and some may be due to chance, though it must be stressed that they are uncommon in the textual tradition up to the fourteenth century:

\section{Shared readings in I II III}

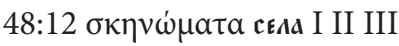

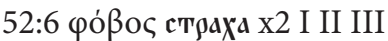

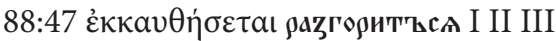

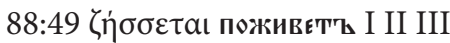

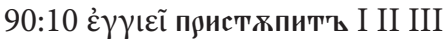

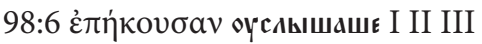

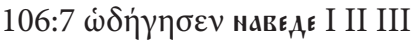

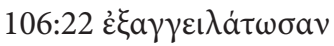

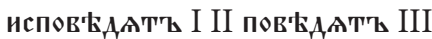

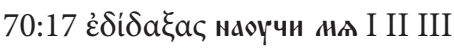

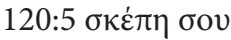

покров' I II покров' твои III

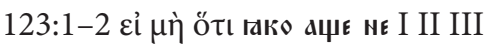

\section{Revisions in Mihanović Psalter and IV}

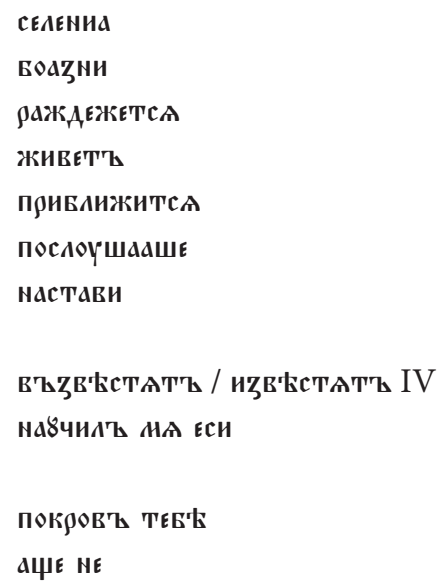

Of more weight are the shared instances of approximation to Greek: standard lexical equivalents, morphological calque, choice of number, case, preposition or word order in direct imitation of Greek, and the use of ижє as a definite article:

\footnotetext{
${ }^{45}$ The manuscript has the following lacunae: pss. 1-40:7, 50:21-end of 51, 67:20-33, 83:7-end of 85 ,
} 87:8-88:26, 91:8-95:8, 104:27-105:23, 108:8-109:3, 115:10-end of 117, 135:7 to the end. 


\section{Shared readings in I II III}

49:14 عủxác ов'Тты I II III

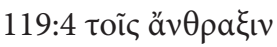

ГорАциняи ХГАьни I II III

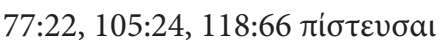

Ати въљы I II III

106:34 картофо́роv пАОдовитж I II III

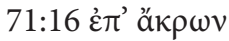

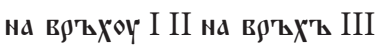

72:21 vечроі втрова нога I II III

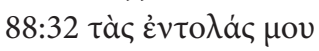

запов'Адии ноих'ъ I II III

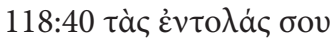

заповъдии твонхъ I II III

118:136 tòv vó

119:7 غ̇ंก $\lambda \dot{\varepsilon} \mu \mathrm{ovv} \mu \varepsilon$

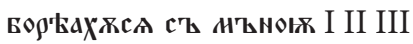

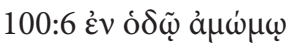

ПО Пхтти неПОЛОчьноY I II III

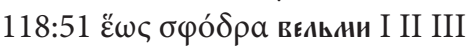

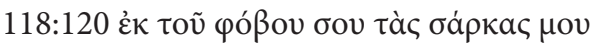

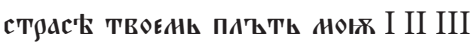

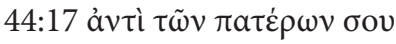

въ бци твонхъ н'стто I II III

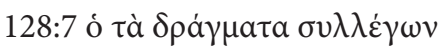

съБирањи бжконти I II III
Revisions in Mihanović Psalter and IV

Mолїтвы

хГА'Мни

в'љовати

ПАOAОNOCH

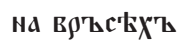

жт९овы Нож

ZAПOBКАุИ HOA

ZАПОВТАИИ ТВОА

ЗаКОн' ТВои

Борт人х нА

В' ПХТИ неПОЛШЧн'

A, grta

ш̈ ст९аха Твоего ПАьти ноА

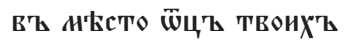

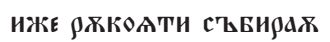

More remarkable still are readings common to the Mihanović and Norov Psalters which derive from variants within the Greek textual tradition:

\section{Greek variants in I II III}

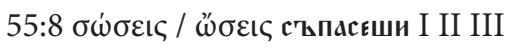

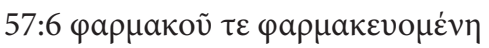

от'Қ... оваваньника оваваєна I

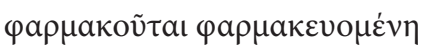

оБаваена оБавањбчисА II

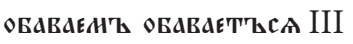

\section{Greek variants in Mihanović Psalter and IV}

ИЗ९ИнєШи

ogabaetca mgabaeha IV

wgazaetca ogazaen'z Mihanović 
61:9 $\dot{\eta} \mu \tilde{\omega} \nu /$ v $\mu \tilde{\omega} \nu$ нашъ I II III

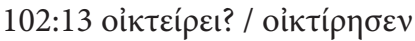

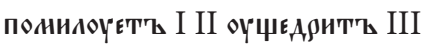

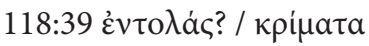

ПовєА'Книта твоґ I II III

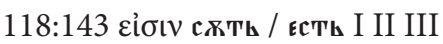

121:8 $\delta$ ウ́ omitted in I II III ваш'ъ

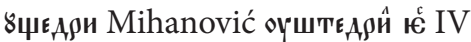

сждБы твон

omitted in Mihanović and IV

$8 \mathrm{5O}$

These are indicative of a revision based on a slightly different Greek text from that used for Redaction III as otherwise attested ${ }^{46}$.

What is more, in the Mihanović Psalter the innovatory and Grecizing tendencies extend beyond the variants which this manuscript shares with the Norov Psalter, to emerge in a scattering of idiosyncratic lexical items, innovatory grammatical forms, choices of case, preposition or word order prompted by Greek, and reflexive verbs in place of passive participles to render Greek medio-passive forms:

\section{Shared readings in I II III IV}

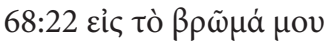

тады н нот I II III IV

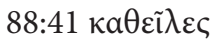

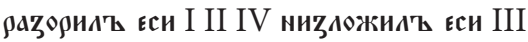

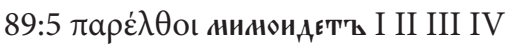

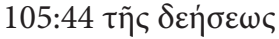

Нолитвж I II III нолитвы IV

61:7 ӧтเ иво I II III IV

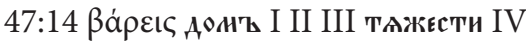

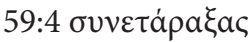

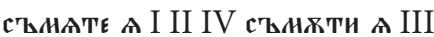

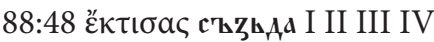

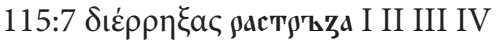

90:9 катафuүฑ่v боv

ПОИБ'ЖЖИЧЕ Твов I II III IV

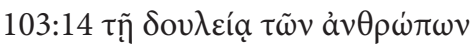

на сАоужьБ及 чАВконт I II III IV

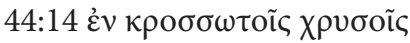

төжсны zлатыы I II IV

\section{Revisions in Mihanović Psalter}

Б९ашно MOE

низАожи

ПОТИАЕТТ'

HOAENHE

тако

вогатеттво

сНКТИАь А Еси

с'ЪҚААА'Қ Еси

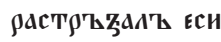

ПОИБ'КЖИЧЕ Сєธ大

слоужьЕ чйчьстьи

${ }^{46}$ C.M. MacRobert, The Textual Tradition of the Church Slavonic Psalter up to the Fifteenth Century, [in:] Interpretation of the Bible, ed. J. KRAšovec, Ljubljana-Sheffield 1998, p. 933. 
९асны zалты III

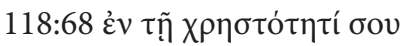

Бдагостинт твоєе I II III IV

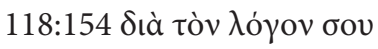

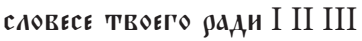

९ади словесе твоегО IV

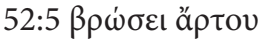

въ ХАТБа м'大сто I II III

въ адық ХА'Ева IV

48:15 عै $\theta \varepsilon v \tau о$

ПОАОЖЕНЫ СХT' I II III IV

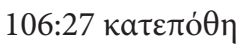

ПОГА'ЪџЕна БЫСт' I II III IV

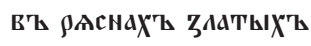

ВЪ БАаГОСТИ ТВОЕИ

ZA CAOBO TBOE

въ пищк ХА'Бь

ПоложишжеА

ПОГАОТИСА

These readings peculiar to the Mihanović Psalter mirror the shared linguistic practices which set it and Redaction IV apart from other versions, and raise the possibility that this manuscript may occasionally preserve traces of revision which have been lost in the Norov Psalter.

The problems of the textual relationship between the Mihanović Psalter and Redaction IV as represented by the Norov Psalter thus replicate those for Redactions III and IV: the parallels between them are too pronounced to be due to mere chance, yet the versions are to some extent independent of each other both in their inheritance from earlier tradition and in their innovations. How are these complexities to be explained?

When considering how deliberate conflation or accidental contamination has arisen between texts, it is important to keep in view the factors which shape the specific textual tradition. In the case of the Church Slavonic Psalter, the first point to bear in mind is that the redeployment of pre-existing translations was intrinsic to the process by which redactions came into being: each new version was a modification of an earlier one. Secondly, because the Psalter was so widely and frequently used, at each successive stage in the development of the text familiarity with a pre-existing redaction was inevitable: the compilers, copiers and early users of revised versions would initially have known the older, unrevised wordings better than the corrected ones. To these circumstances must be added more general considerations which bear on the revision of texts in manuscript: the production of a complete new copy was expensive of time and material, but the alternative option, correction of an extant manuscript, was laborious and difficult to carry through systematically. Scribes conscious of the potential for error - the part played by memory and inadvertence in the processes of copying or correction 
- might seek to control their text by consulting more than one exemplar, only to introduce further contamination ${ }^{47}$.

Several different ways can be envisaged in which a mixture of variants from different redactions might come to coexist in witnesses to the Church Slavonic psalter tradition:

Type 1. When a scribe worked from an exemplar containing a pre-existing version of the Church Slavonic text, but modified the text, more or less consistently, either by inserting corrections or by emending as he copied on the basis of recurrent reference to Greek. This is likely to have been the process by which the Church Slavonic version of Theodoret's commentary on the psalms was produced in the tenth century, since it reflects a different set of Greek variant readings from those characteristic of Redaction I, but betrays the lingering influence of that redaction in certain lexical inconsistencies ${ }^{48}$. A parallel consultation of Latin gave rise to the Croatian Church Slavonic modification of Redaction I.

Type 2. When a scribe produced a copy of a new redaction by introducing corrections, more or less consistently, into a manuscript containing an older version of the text. Such an expedient might be adopted if the exemplar of the new redaction was available only for a limited time on loan, or if the cost of an entirely new manuscript could not be met. This practice is instantiated in the fourteenthcentury manuscripts Peć $68^{49}$ and F.n.1.3. ${ }^{50}$, where it can immediately be detected by large numbers of overwritten erasures.

Type 3. When a scribe chose to work from more than one Church Slavonic exemplar, as explicitly indicated in the colophon to Sinai $9 \mathrm{a}^{51}$. The concurrent use of multiple exemplars may be signalled by alterations in mid word or mid phrase, for instance in Sinai $9 \mathrm{a}^{52}$ and in the Oxford Psalter ${ }^{53}$, by conflation of distinct textual types, as in those East Slavonic manuscripts of the late fourteenth and early fifteenth centuries which draw on the two Church Slavonic translations of commentaries

\footnotetext{
${ }^{47}$ R. Pope, On Contamination, Multiple Exemplars, and Establishing the History of Collated Texts, [in:] Русь и южные славяне. Сборник статей к 100-летию со дня рождения В.А. Мочина (1894-1987), еd. В.М. ЗАгреьин, Санкт-Петербург 1998, р. 289-294.

${ }^{48}$ В.А. Погорелов, Толкования Феодорита Киррского на Псалтырь в древне-болгарском переводе. Рассмотрение списков и исследование особенностей Псалтырного текста, Варшава 1910, p. 113-116; J. LéPIssier, Les Commentaires des Psaumes de Théodoret, Paris 1968, p. 3-4, 304-306.

${ }^{49}$ C.M. MacRobert, Two for the Price of One: the Psalter MS Peć 68, OSP, New Series 22, 1989, p. 1-33.

${ }^{50}$ C.M. MacRobert, The historical significance of the Frolov Psalter (Russian National Library, F.n.I.3), WS 42, 1997, p. 34-46.

${ }^{51}$ Е.В. Чешко, Об абонской редакиии..., p. 61.

${ }^{52}$ C.M. MacRobert, What was the izvod Svetogorski?, [in:] Pусь и южные славяне..., p. 274-275.

${ }^{53}$ C.M. MacRobert, The Textual Tradition of the Oxford Serbian Psalter MS e Mus 184, ПК, 25/26, 1994, p. 147-148.
} 
on the psalms $s^{54}$, or by a clear switch from one textual tradition to another within a single manuscript ${ }^{55}$. It implies the existence of competing redactions, or at least uncertainty on the scribe's part about the authority of the versions available to him.

Type 4. When readings from a different redaction, typically a more recent one, were added to a manuscript on an unsystematic basis, as an afterthought by the scribe himself or by a subsequent reader. This might be done either by erasure and correction, e.g. in the psalter manuscripts Sinai 7 and 8 and the Athens Psalter ${ }^{56}$, or by marginal or interlinear glossing, as in the two Sinai Glagolitic Psalters ${ }^{57}$.

Type 5. When a scribe copying a new version of the text reverted sporadically to an older version which he knew by heart. Interference by memory probably explains the occasional variants characteristic of Redaction II which can be detected in manuscripts primarily affiliated to Redaction I, e.g. the fourteenth-century commentated Sofia Psalter ${ }^{58}$, or to Redaction III, e.g. the Munich Psalter ${ }^{59}$.

Type 6. When revisers worked independently but against a similar linguistic background, on similar, typically literalistic, translational principles, or from the same Greek textual tradition, and so might arrive at the same wording by pure coincidence. This possibility has to be kept in view in evaluating some of the more literal variants in the manuscripts under consideration in this study. For instance,

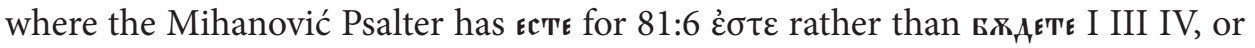

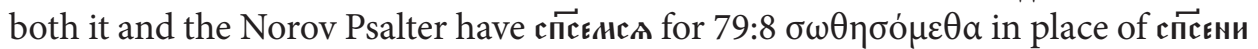

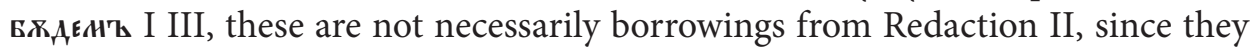
are typical of the fourteenth-century approach to translation. For the same reason, there is no need to assume that the Norov Psalter took naчsad for 138:17 ai a $\rho$ Xai directly from the Sinai Glagolitic Psalter in preference to the usual Church Slavonic translation владычьствиг in Redactions I II and III.

\footnotetext{
${ }^{54}$ C.M. MAcRobert, The compilatory Church Slavonic catena on the Psalms in three East Slavonic manuscripts of the fifteenth and sixteenth centuries, Sla 74.2/3 (2005) (CyrilloMethodiana 2005 ad honorem Zdeňka Ribarova et Ludmila Pacnerová), p. 213-238.

${ }^{55}$ C.M. MacRobert, Alphabetic suspension in Glagolitic and Cyrillic manuscripts, Slo 56/57, 2007, p. 324-327. Е.В. ЧЕшко, Об абонской редакции..., p. 86-91, suggests that a change of exemplars, from Redaction V to Redaction III, can be detected in the Kiev Psalter, but this is doubtful, since the latter part of this manuscript contains variants alien to Redaction III, see C.M. MAcRoberT, The impact of interpretation on the evolution of the Church Slavonic psalter text up to the fifteenth century, [in:] Congress Volume Ljubljana 2007, ed. A. Lemaire [= Supplements to Vetus Testamentum, vol. 133], Leiden-Boston 2010, p. 431.

${ }^{56}$ C.M. MacRobert, On the role of memory and oral tradition in the early transmission of the Church Slavonic psalter text, [in:] Християнска агиология и народни вярвания. Сборник в чест на ст. н. с. Елена Коцева, еd. А. Милтенова, Е. Томова, Р. Станкова, София 2008, р. 341.

${ }^{57}$ C.M. MacRobert, On the headings..., p. 179-183.

${ }^{58}$ For examples, see И. КАРАЧОРОВА, ор. cit., p. 185-188, and the use of вєзоүнд in 34:7 and 19, which is characteristic of Redaction II.

${ }^{59}$ E.g. the typical Redaction II reading in 62:2 како простреттск.
} 
The outcomes of these different processes can be distinguished from each other when direct evidence for Type 2, 3 or 4 is available, in the form of scribal comment or detectable correction. Types 1 and 2 may also be distinguishable from Type 4 in quantitative terms, because they are likely to produce a preponderance of readings from the newer target version. The same consideration may apply to Type 3, but only if the scribe has given clear priority to one version among those on which he draws, or has made a clean change from one version to another in the course of his work.

However, once the manuscript in which the conflation or contamination took place was re-copied, any type could result in a text which mainly follows one redaction but contains sporadic readings from another. So Pope suggests that doublet readings are indicative of Type $3^{60}$, and they are indeed a feature of the early fifteenth-century compilatory catenas on the psalms from the Jaroslavl' and Barsov collections and the related Luck Psalter of $1384^{61}$; but he concedes that doublets might also appear when a manuscript containing glosses of Type 4 was copied by a scribe who incorporated them into the text. The operation of Type 5 could likewise give rise to doublet readings, if a scribe wrote a word or phrase from memory, then realised that his exemplar contained a different wording, and added it rather than make a correction. Possible examples of this kind occur in the Luck Psalter ${ }^{62}$; their interpretation as instances of Type 5 contamination relies on the information provided in the colophon, that the scribe wrote in haste and the fear of death.

Where a combination of the processes enumerated above was in operation, the outcome was liable to be correspondingly complex. For instance, the scribe of the Bucharest psalter probably worked from two manuscripts, a commentated version of Redaction I from which he reproduced the Church Slavonic translation of the pseudo-Athanasian commentary, and the newly introduced Redaction III of the simple Psalter. It is hardly surprising that the resulting text of the psalms themselves is an unpredictable mixture of the two redactions ${ }^{63}$, nor that occasionally variants typical of Redaction II have crept in ${ }^{64}$, presumably because this version was still familiar to the scribe from liturgical practice in the early fourteenth century. The alternative interpretation put forward by Karačorova ${ }^{65}$, that the readings in this manuscript which are typical of Redaction III crept in by Type 5 contamination, relies on the assumption that Redaction III was already so well established by 1346 that the scribe of the Bucharest Psalter could have known it by heart, and so begs the question of dating.

\footnotetext{
${ }^{60}$ R. Pope, On Contamination..., p. 290.

${ }^{61}$ C.M. MacRobert, The compilatory Church Slavonic catena..., p. 222-223; EAdem, The textual peculiarities of the Luck Psalter of 1384 (Acquisti e Doni MS 360, Biblioteca Medicea Laurenziana, Florence), RS. New Series 8 (54), 2010, p. 106.

${ }^{62}$ C.M. MacRobert, The textual peculiarities..., p. 107-110.

${ }^{63}$ EAdEM, Problems..., p. 201, 211.

${ }^{64}$ E.g. ps. 34:19 вєзоүна, ps. 39:8 вь ГАавизн' книжн'Ень, ps. 62:2 како простретеє.

${ }^{65}$ И. КАРАЧОРОВА, КбМ вбпроса..., p. 243.
} 
Allowance has also to be made for the provenance and dissemination of specific versions. For example, the fourteenth-century East Slavonic manuscript Typ.34 was patently copied from the commentated version of Redaction I, which is not otherwise attested from the East Slavonic area after the twelfth century; but it also contains readings characteristic of Redaction $\mathrm{II}^{66}$. In principle this copy could be an instance of Type 3, if we assume that the scribe worked from two manuscripts; but this assumption seems unlikely - why should a scribe have chosen to make such a conflation? - and unnecessary, since the scribe's deviations from Redaction I can more plausibly be explained as an instance of Type 5: given the peculiar difficulties of producing a simple copy of the psalms from an unfamiliar commentated redaction, the scribe was more than usually liable to revert to the version of the text most widely used and known among the East Slavs up to the late fourteenth century, i.e. Redaction II.

In the South Slav lands, by contrast, Redaction I and Redaction II continued to be used interactively at least up to the fourteenth century, giving rise to manuscripts of hybrid textual character, probably by Type 5 contamination ${ }^{67}$. This state of textual fluidity no doubt contributed both to renewed interest in recognizably conservative versions and to the demand for new revised texts securely based on Greek. Consequently the mixture of features characteristic of Redactions I and II which is observable in Redaction III is open to more than one interpretation. It could be the outcome of deliberate conflation by Type $3^{68}$; but to undertake such a complex process of revision, consulting more than one Church Slavonic manuscript as well as the Greek text, would surely have been justified only by the wish to reconcile competing authoritative versions ${ }^{69}$. At present we lack evidence that Redactions I and II of the Psalter had such a status in the South Slav lands towards the end of the thirteenth century; it is not even clear how far they were recognized as distinct from each other. An alternative hypothesis is that Redaction III is a product of Type 1: that it was copied from a pre-existing version in current use - inevitably to some extent a hybrid - with systematic checking against Greek and some linguistic normalization. Under this hypothesis the shared characteristics

${ }^{66}$ C.M. MAcRobert, A Missing Link in the Early Tradition of the Church Slavonic Psalter (the Tolstoy, Sluck, Eugenius and Vienna Psalters and MS 34 of the Moscow Synodal Typography), WSJ 39, 1993, p. 63-65. ${ }^{67}$ C.M. MAcRobert, On the role of memory..., p. 345-351.

${ }^{68}$ This seems to be implied by the suggestion that Redaction II functioned as a 'коректив' for the fourteenth-century revised versions, sеe И. КАРАчоровА, Кбм въпроса..., p. 183. Deliberate conflation of earlier redactions is likewise posited for the Athonite revision of the Apostol, see И. ХРИСтовА-Шомова, Служебният Апостол в славянската ръкописна традиция, 1. Изследване на библейския текст, София 2004, p. 771.

${ }^{69}$ Type 3 conflation is more plausible as a stage in the genesis of Redaction V, which seems to have been a compromise between the recently compiled and still authoritative Redactions III and IV with some limited supplementary reference back to Greek, see F. J. Thomson, op. cit., p. 823-825. For an alternative view, based on selective material, of Type 6 convergence between Redactions IV and V, see Т.А. Афанасьева et al., Языковые инновации в переводах, связанных с именем Киприана, Slov 1, 2015, p. 21-26. 
of Redactions II and $\mathrm{III}^{70}$ can for the most part be explained either by reference to a common Greek textual tradition or as instances of grammatical and lexical trends which operated from the tenth century onwards.

But how do the Mihanović Psalter, apparently an early witness to Redaction III, and the Norov Psalter, the sole representative of Redaction IV, fit into the picture? Trivially they are both examples of Type 4: each has been sporadically corrected in later hands and inks to Redaction $\mathrm{III}^{71}$, thus corroborating the view that this redaction predominated in the South Slav lands. Considered in isolation, each could be an example of Type 2 or 5: either a manuscript containing an older version was corrected, somewhat inattentively, to bring it in line with Redaction III, or Redaction III was copied by a scribe who introduced older readings from memory; Type 3 conflation, though possible in principle, is less likely, for the reasons set out above. At the same time changes, systematic in the Norov Psalter, sporadic in the Mihanović Psalter, were made to align wording more closely with Greek. Once again these accounts presuppose some concurrent use of more than one Church Slavonic version, plus consultation of Greek. They also depend on the assumption, for which we lack decisive independent evidence, that Redaction III was already in existence when the manuscripts were written ${ }^{72}$.

However, if the textual peculiarities of the two manuscripts are considered together, the inadequacy of these interpretations becomes apparent: they fail to explain the shared distributions of inherited material, innovations, and distinctive Greek variants in the Norov and Mihanović Psalters. If it is conceded that these patterns are not merely fortuitous, then we can infer that the two manuscripts derive, whether immediately or at a small remove, from a common source, which we may call Version $\mathrm{X}$. To this stage in transmission we may refer:

- with confidence, the shared textual and linguistic features, both old and new, of the Mihanović and Norov Psalters;

- with reasonable probability, the shared textual and linguistic features of Redaction III and the Norov Psalter in places where the Mihanović Psalter is defective;

\footnotetext{
${ }^{70}$ И. КАРАЧОРОВА, Кбм въпроса..., p. 183-197.

${ }^{71}$ Е.В. Чешко et al., Норовская псалтырь..., I, p. 80 on corrections mainly to the first 17 psalms.

${ }^{72}$ The dating of Redaction III is a matter of ongoing debate: for instance, Е. КоцевА, Към състава на три ргкописи от Националната библиотека в Собия: Енински апостол, Шопов-Карадимов псалтир и Софийски апостол (НБКМ 882), СЛ, 47, 2013, p. 280-283, argues that the textual antecedents of the Šopov-Karadimov may go back into the thirteenth century, while К. ПАвликянов, Духовная и филологическая деятельность иноков славянского происхождения в Великой Лавре святого Абанасия Абонского в XIV-XV веках, [in:] Абон и ставянский мир. Сборник I. Материаль международной научной конферениии, посвященной 1000-летию присутствия русскиз на Святой горе, еd. Ж.Л. ЛевшниА, Athos 2014, p. 73-80, suggests that the 'Athonite' revisions took place in the 1340s-50s. If Redaction III of the Psalter is identified with the 'Athonite' revision, the latter dating is difficult to reconcile with the attestation of this redaction in manuscripts, particularly in the Bucharest Psalter of 1346.
} 
- conjecturally, the conservative readings of the Norov Psalter where the Mihanović Psalter is defective, though these could alternatively be due to secondary contamination when the Norov Psalter was copied;

- also conjecturally, the idiosyncratic innovations in the Mihanović Psalter where the Norov Psalter either innovates differently or reverts to the readings of older redactions.

This leaves two sets of data in need of explanation:

- conservative readings in the Mihanović Psalter where the Norov Psalter innovates independently of Redaction III: these might belong to Version X, or might be secondary contaminations;

- conservative readings in either manuscript where the other agrees with Redaction III, to which Version X seems to have been closely allied: these are most numerous in the Norov Psalter, but also figure in the Mihanović Psalter.

Unless we assume that some of the readings which the Norov Psalter shares with Redaction III independently of the Mihanović Psalter are instances of Type 6 coincidence, they preclude the possibility that the Mihanović Psalter could itself have been an exemplar for the Norov Psalter. A parallel conclusion can be drawn from the presence of Redaction III readings in the Mihanović Psalter where the Norov Psalter has conservative ones; in any case the likelihood that the Mihanović Psalter, which lacks such peculiarities as double prefixation on verbs and combinations of єжє ог вьнєгдА with infinitives, could have been copied from the Norov Psalter is remote.

There is more than one way of envisaging the relationship between Version $\mathrm{X}$ and Redaction III. One possibility is an elaboration of Thomson's hypothesis, which can be represented as follows:

\section{Schema 1}

\section{Redaction III}
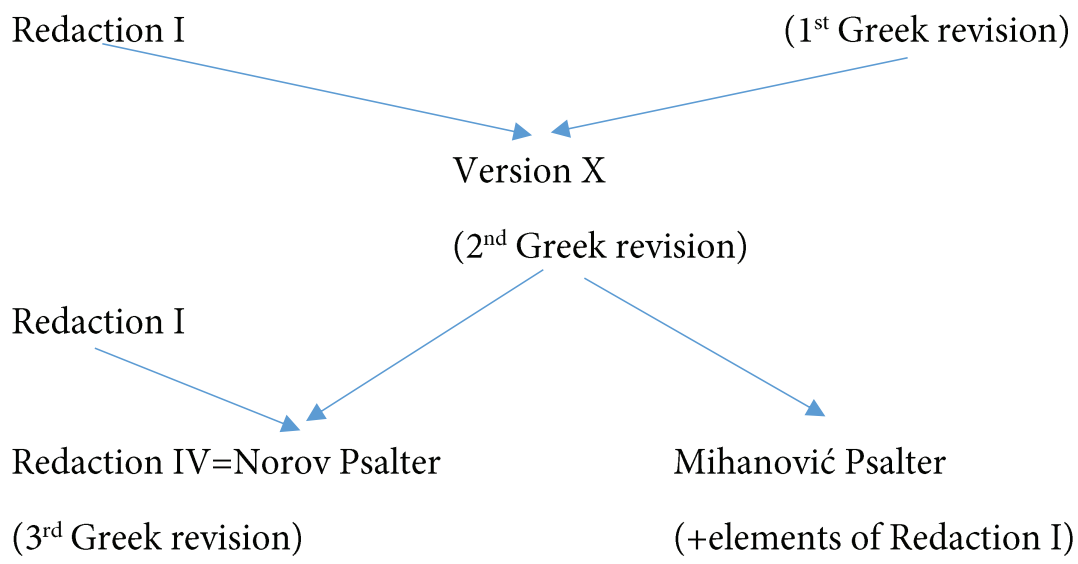

This schema presupposes that Redaction III, a Type 1 revision starting from some blend of Redactions I and II, produced a moderate approximation to Greek 
in the late thirteenth century; that Version X, a Type 2 copy of Redaction III using a conservative manuscript of Redaction I with some further piecemeal revision against Greek, is reflected in the Mihanović Psalter, which underwent some additional Type 5 contamination in the process of copying; and that the Norov Psalter is in turn a Type 2 copy of Version X, also using a manuscript of Redaction I but with more thorough and literalistic revision on the basis of Greek to produce Redaction IV. So this view involves three successive stages of increasingly systematic revision against Greek, and implies that both the inconsistencies shared by the Mihanović and Norov Psalters and those peculiar to the Norov Psalter alone result from imperfect reproduction of Redaction III.

An alternative possibility is to take Version $\mathrm{X}$ as the starting point for change in the late thirteenth or early fourteenth century:

\section{Schema 2}

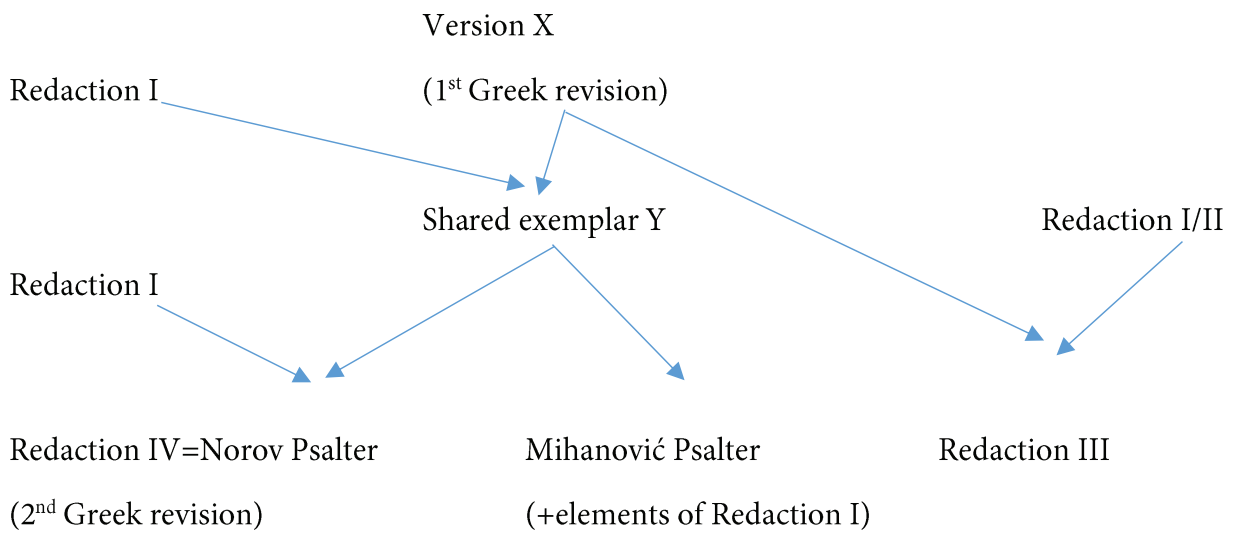

This schema assumes that Version X was a Type 1 revision starting from Redaction I (perhaps with a small admixture of Redaction II readings) with thorough but not slavish reference to Greek; that this gave rise to Y, a Type 2 copy using a manuscript of Redaction I; that $\mathrm{Y}$ was the exemplar for both the Mihanović Psalter, which stands close to it, albeit with some Type 5 reversions to Redaction I, and for the Norov Psalter, another Type 2 copy but with further literalistic revision against Greek; and that other manuscripts of Redaction III derived from a conflation of Version X with older readings by Type 2 or Type 3 in the first half of the fourteenth century. On this view, only two revisions on the basis of Greek have to be posited ${ }^{73}$, but the first of these, in Version X, has to be reconstructed from the combined witness of the Mihanović and Norov Psalters and Redaction III. Each

\footnotetext{
${ }^{73}$ This position is consistent with the absence from Redaction III of distinctive variant readings based
} on Greek, see C.M. MacRobert, The Textual Tradition of the Church Slavonic Psalter..., passim. 
of these contains elements of Version X, such as the use of reflexive verbs with passive function in the Mihanović and Norov Psalters, the instances of понаzаныи in the Norov Psalter and Redaction III; but each, including Redaction III, is an imperfect witness to Version $\mathrm{X}$ because all of them have undergone types of contamination or conflation.

This tentative conclusion raises further questions in turn. More attention needs to be paid to traces of possible influence from Redaction IV in psalter manuscripts of the fourteenth and fifteenth centuries. Such influence has been detected in Redaction V, the version of the psalms supposed to have been the psalter translation promoted by Metropolitan Kiprian and later incorporated into the Gennadian Bible. Readings characteristic of Redaction IV also appear in some South and East Slavonic manuscripts of the later fourteenth and early fifteenth centuries, particularly the Serbian Oxford Psalter ${ }^{74}$ and the catenas on the psalms in the Jaroslavl' and Barsov collections. More investigation of manuscripts from this period may clarify the picture.

The other open issue is the identification of the 'Athonite' redaction of the Psalter. Since the 1980s Redaction III has been regarded as Athonite in provenance; but the evidence for this association is open to question, since it relies on generalizing Popov's interpretation ${ }^{75}$ of the word izvod as 'translation' and by extension '(new) version', rather than its usual sense of 'copy, manuscript ${ }^{76}$. Moreover, investigations of the Athonite redactions of other Church Slavonic translations suggest that their linguistic usage and approach to translation ally them more closely with Redaction IV. Hristova-Šomova finds that the Athonite revision of the Apostol is characterized by the use of the animate accusative, reflexive verbs in passive function, ижє / єжє as equivalents to Greek definite articles, particularly in combination with infinitives, multiple prefixation on verbs in imitation of Greek, and increased occurrence of the pronoun $\mathrm{m}_{\mathbf{2}} \mathbf{7}^{77}$. Yet in the textual tradition of the Church Slavonic Psalter these usages are more prominently attested in Redaction IV than in Redaction III. Both Taseva's summary overview of linguistic usage in early fourteenth century revisions ${ }^{78}$ and the more detailed analysis provided by Taseva and Jovčeva $^{79}$ list nominalized infinitives and infinitival clauses among the distinguishing

\footnotetext{
${ }^{74}$ C.M. MacRobert, The Textual Tradition of the Oxford Serbian Psalter..., ПК, 25/26, 1994, p. 152-154; EADEM, Maksim Grek in linguistic context.

${ }^{75}$ Г. Попов, Новооткрито сведение за переводческа дейност на бблгарските книжовници от Света гора през първата половина на XIV в., БЕ, 5, 1978, р. 402-410.

${ }^{76}$ C.M. MAcRoBert, What was the izvod Svetogorski?, p. 272, 280-281.

${ }^{77}$ И. Христова-ШомовА, Служебният Апостол в славянската ръкописна традиция, 1. Изследване на библейския текст, София 2004, р. 771-777.

78 Л. ТАСевА, Езикбт на книжнината през XIV век, [in:] История на българската средновековна титература, еd. А. МилтеновА, София 2008, р. 569-574.

79 Л. ТАСева, М. ЙовчевА, Езиковите образиц на атонските редактори, [in:] Българска филологическа медиевистика. Сборник. Научни изследвания в чест на профб. дфн Иван Хара-
} 
features of the Athonite redactions, but in the Psalter these are occasionalisms in Redaction III; they are deployed systematically only in Redaction IV. The use of Redaction III of the Church Slavonic Psalter as a guide to Athonite translational practice is therefore open to question and, if uncritically accepted, may lead to distortion in our picture of linguistic norms and trends in the early fourteenth century.

\section{Bibliography}

\section{Primary sources}

Mihanović Psalter, Hrvatska akademija znanosti i umetnosti, III a 49, and Nacionalna i sveučilišna knjižnica u Zagrebu, R. 4494/1.

Norov Psalter, [in:] Норовская псалтырь: Среднеболгарская рукопись XIV века, I-II, ed. Е.В. ЧЕшко et al., София 1989.

\section{Secondary literature}

Jagić V., Zwei illustrierte serbische Psalter (= introduction to J. Strzygowski, Die Miniaturen des Serbischen Psalters der Königlichen Hof- und Staatsbibliothek in München), DKAW.PhH 52.2, 1906, p. 1-95.

LÉPIssier, J., Les Commentaires des Psaumes de Théodoret, Paris 1968.

MacRobert C.M., Two for the Price of One: the Psalter MS Peć 68, OSP. New Series 22 (1989), p. 1-33.

MacRobert C.M., A Missing Link in the Early Tradition of the Church Slavonic Psalter (the Tolstoy, Sluck, Eugenius and Vienna Psalters and MS 34 of the Moscow Synodal Typography), WSJ 39 (1993), p. 57-81.

MacRobert C.M., The Textual Tradition of the Oxford Serbian Psalter MS e Mus 184, ПК, 25/26, 1994, p. 146-154.

MacRobert C.M., Problems in the study of the 'Athonite' redaction of the Psalter in South Slavonic manuscripts, [in:] Studies of Medieval South Slavic Manuscripts. Proceedings of the $3^{\text {rd }}$ International Hilandar Conference held from March 28 to 30, 1989 = Проучаване средновековних јужнословенских рукописа. Зборник радова са III међународне Хиландарске конферениије одржане од 28. до 30. марта 1989, еd. П. Ивић, Београд 1995, р. 195-213.

MacRobert C.M., The historical significance of the Frolov Psalter (Russian National Library, F.n.I.3), WS 42, 1997, p. 34-46.

MacRobert C.M., What was the izvod Svetogorski?, [in:] Русь и южные славяне. Сборник статей к 100-летию со дня рождения В. А. Мочина (1894-1987), ed. В.М. ЗАГРеБИн, Санкт-Петербург 1998, р. 272-283.

MacRobert C.M., The Textual Tradition of the Church Slavonic Psalter up to the Fifteenth Century, [in:] Interpretation of the Bible, ed. J. KRAšovec, Ljubljana-Sheffield 1998, p. 921-942.

тампиев по случай 60-годишния му юбилей, ed. А. ДАвидов et al., Велико Търново 2006, p. 221-240. It is clear from the footnotes which they provide on each point that they rely for information about the Psalter on Karačorova's study of 1989, the primary aim of which was to highlight the differences between fourteenth-century linguistic practice and earlier versions, rather than the divergences between Redactions III and IV. 
MacRobert C.M., The compilatory Church Slavonic catena on the Psalms in three East Slavonic manuscripts of the fifteenth and sixteenth centuries, Sla, 74.2/3, 2005 (CyrilloMethodiana 2005 ad honorem Zdeňka Ribarova et Ludmila Pacnerová), p. 213-238.

MAcRobert C.M., The variable treatment of clitics in $14^{\text {th }}$-century South Slavonic psalter translations, [in:] Многократните преводи в Южнославяското Средновековие. София, 7-9 юли 2005, ed. Л. ТАСЕвА, Р. МАРТИ, М. ЙовчевА, Т. ПЕНТКОВСКАЯ, СофИя 2006, p. 373-395.

MacRobert C.M., Alphabetic suspension in Glagolitic and Cyrillic manuscripts, Slo 56/57, 2007, p. 319-332.

MacRobert C.M., On the role of memory and oral tradition in the early transmission of the Church Slavonic psalter text, [in:] Християнска агиология и народни вярвания. Сборник в чест на cm. н. с. Елена Коцева, еd. А. Милтенова, Е. Томова, Р. Станкова, София 2008, p. 340-355.

MACRoBert C.M., The impact of interpretation on the evolution of the Church Slavonic psalter text up to the fifteenth century, [in:] Congress Volume Ljubljana 2007, ed. A. Lemaire [Supplements to Vetus Testamentum, vol. 133], Leiden-Boston 2010, p. 423-440.

MacRobert C.M., The textual peculiarities of the Luck Psalter of 1384 (Acquisti e Doni MS 360, Biblioteca Medicea Laurenziana, Florence), RS. New Series 8 (54), 2010, p. 101-125.

MacRoвert C.M., On the headings and marginal notes in the two Glagolitic psalter manuscripts in S. Catherine's Monastery on Mount Sinai, [in:] Philology Broad and Deep: In Memoriam Horace Gray Lunt, ed. M. S. Flier, D. J. Birnbaum, C.M. Vakareliyska, Bloomington, IN 2014, p. $175-185$.

MacRobert C. M., Maksim Grek in linguistic context, [forthcoming in:] Latinitas in the Slavic World, ed. V.S. TOMELLERI $[P h S]$.

Mošın V., Ćirilski rukopisi Jugoslavenske akademije, Zagreb 1955, I, p. 55-56, II, p. 13-14.

Pope R., On Contamination, Multiple Exemplars, and Establishing the History of Collated Texts, [in:] Русь и южные славяне. Сборник статей к 100-летию со дня рождения В. А. Мочина (1894-1987), еd. В.М. ЗАГРЕБин, Санкт-Петербург 1998, р. 289-294.

Rahlfs A., Septuaginta, vol. X, Psalmi cum Odis, Göttingen 1979³.

Thomson F.J., The Slavonic Translation of the Old Testament, [in:] Interpretation of the Bible, ed. J. KRAŠoveC, Ljubljana-Sheffield 1998, p. 605-920, especially p. 797-825.

Афанасьева Т.A. et al., Языковые инновации в переводах, связанных с именем Киприана, Slov 1, 2015, p. 13-38.

КАРАчорова И., Към въпроса за Кирило-Методиевския старобългарски превод на псалтира, KMc 6, 1989, p. 130-245.

КАРАчорова И., Към изучаването на псалтирните редакиии от XIV в. (Библейски песни), [in:] ...Нноть оученикъ надъ оучителемь своимъ. Сборник в чест на проф. дфн Иван Добрев, член-кореспондент на БАН и учител, еd. А.-М. ТотомАновА, Т. СлАвовА, София 2005, p. 345-356.

Коцева Е., Към състава на три ръкописи от Националната библиотека в София: Енински апостол, Шопов-Карадимов псалтир и Софийски апостол (НБКМ 882), СЛ, 47, 2013, p. 275-294.

МАртиновић Д., Псалтир с последованем Ђурђа Црнојевића 1494, Cetinje 1986.

Мусакова Е., Новооткрит фрагмент от Шоповия-Карадимов псалтир, [in:] Богослужебните книги - познати и непознати, София 2008, р. 27-35. 
ПАвликянов К., Духовная и филологическая деятельность иноков славянского происхождения в Великой Лавре святого Афанасия Афонского в XIV-XV веках, [in:] Афон и славянский мир. Сборник I. Материаль международной научной конференции, посвященной 1000летию присутствия русскиз на Святой горе, ed. Ж.Л. ЛввшниА, Athos 2014, p. 73-80.

Погорелов В.А., Толкования Феодорита Киррского на Псалтырь в древне-болгарском переводе. Рассмотрение списков и исследование особенностей Псалтырного текста, Варшава 1910.

Попов Г., Новооткрито сведение за переводческа дейност на българските книжовници от Света гора през първата половина на XIV в., БЕ 5, 1978, p. 402-410.

ТАСева Л., Езикът на книжнината през XIV век, [in:] А. Милтенова et al., История на българската средновековна литература, София 2008, p. 569-574.

ТАсева Л., М. ЙовчевА, Езиковите образци на атонските редактори, [in:] Българска филологическа медиевистика. Сборник. Научни изследвания в чест на проб. дфн Иван Харалампиев по случай 60-годишния му юбилей, ed. А. ДАвидов et al., Велико Търново 2006, p. 221-240.

Турилов А.А., Болгарские книжники раннего XIV в. между Тырновом, Святой горой и Святой землей, КМс 21, 2012, p. 236-244.

Христова-Шомова И., Служебният Апостол в славянската ръкописна традиция, 1. Изследване на библейския текст, София 2004.

ЧЕшко Е.В., Об афонской редакиии славянского перевода псалтыри в ее отнотении к другим редакциям, [in:] Язык и письменность среднеболгарского периода, ed. Е.В. Чешко et al., Москва 1982, р. 60-93.

ЧЕшко Е.В., Кирилло-мефодиевский перевод Псалтыри и среднеболгарские правленые редакици. Структура слова и реляиионные элементы, [in:] Studia slavico-byzantina et mediaevalia europensia, I, ed. П. Динеков et al., София 1988, p. 217-230.

Чешко E.B. et al., Норовская псалтырь: Среднеболгарская рукопись XIV века, I-II, София 1989.

\begin{abstract}
Modern scholarship on the textual history of Church Slavonic biblical translation recognizes two distinct revisions of the Church Slavonic Psalter from the early fourteenth century, Redaction III (sometimes called the 'Athonite' redaction) and Redaction IV, known only in the Norov psalter manuscript. Although they are both attested from the same period and in manuscripts of similar Bulgarian provenance, these two redactions are in some respects systematically different in their linguistic character, their approach to translational issues and their Greek textual basis. In the light of A.A. Turilov's observation that the Mihanović Psalter, possibly the earliest witness to Redaction III, is written in the same hand as the greater part of the Norov Psalter, this paper examines the textual antecedents of the two redactions and the importance of the Mihanović Psalter as a link between them.
\end{abstract}

Keywords: Church Slavonic Psalter, 'Athonite' redaction, conflation, contamination.

\title{
Catherine Mary MacRobert
}

Faculties of Medieval and Modern Languages and of Linguistics, Philology and Phonetics University of Oxford Lady Margaret Hall, Norham Gardens OX2 6QA Oxford, UK catherine.macrobert@lmh.ox.ac.uk 